\title{
Applying a Metaphorical Method in Career Counselling
}

\author{
Anita Racene Dr. paed., Mg. oec. \\ Latvia University of Life Sciences and Technologies, Latvia \\ anita.racene@1lu.lv
}

\begin{abstract}
The present paper presents the research results on the role of choosing the metaphorical method for career counselling. The research aims to analyse the results of applying the metaphorical method in career counselling. An analysis of relevant theories and the results of an assignment completed by students of professional education institutions was performed to achieve the aim. The study involved 19 students aged 18-30. The research found that metaphors stimulate the imagination of young individuals and allow them to creatively approach career investigation by using their potential for a complex understanding of career-related phenomena and thinking about their career development. The research results could contribute to the understanding of the role of applying metaphorical methods in career counselling and give an idea of young individuals' creativity and imagination in connection with their career development. Career counsellors, teachers as career counsellors and personnel selection specialists could use the findings in their career counselling practice.
\end{abstract}

Keywords: metaphors, metaphorical methods, career counselling, career counsellor.

\section{Introduction}

Career education as systematic cooperation between educational institutions, parents and the public provide support to young individuals to choose their career paths independently. Career support, which is implemented through various activities, includes information, career education as well as both group and individual counselling. Career counsellors help young individuals to develop themselves and make informed career choices (Dislere, Vronska, 2020; Briska, Dislere, 2018; Racene, 2013). The activity of a career counsellor in professional education institutions is appreciated and supported, thereby reducing the number of young individuals who are unable to find suitable jobs for themselves.

Individuals use three types of instruments to get results when they interact with other individuals, which are as follows (Vygotsky, Luria, 1994):

1) psychological (symbolic) instruments;

2) technical instruments;

3) intermediaries (identity as an instrument).

Identity is a component of the individual's psyche, which both manages and regulates the individual's aspirations, wishes and interests, as well as reflects the performance of this manager and regulator.

Psychological (symbolic) instruments are called mental instruments. From a socio-dynamic perspective, all man-made instruments are called cultural instruments, which could be divided into two types of instruments: technical and mental (Vygotsky, Luria, 1994).

Any mental (or psychological) instrument is symbolic; therefore, mental instruments also include all phenomena of language: individual sounds, alphabet, words and sentences, as well as very complex instruments, such as stories, texts, charts, maps, musical scores, plays and literary works. They are also man-made; therefore, they could also be considered to be cultural artefacts.

A technical instrument refers to a non-symbolic object, such as a computer, a chair, an engine, a pencil, a cup and a radio. Many technical instruments are complex and consist of technical parts that are combined in one larger instrument. All technical instruments are man-made; therefore, they are cultural artefacts (Peavy, 2004).

It is important to perceive words as instruments, and individuals use words to achieve something. Career counsellors use both technical and mental instruments in their daily practice. Technical instruments, such as a computer, telephone, pencil, paper sheet, chair and dictaphone are important in the work of a modern counsellor, yet mental instruments - words, sentences, ideas, metaphors, stories, intonations, texts, pictures, diagrams, maps and models - are even more common. 
Metaphors are human inventions that are used as instruments of mind to describe and re-describe identity, social interaction, human activity and society. Individuals use instruments to do something. The instrument points to a specific function or set of functions. The term instrument partly replaces the term psychological technique (Peavy, 2004).

A career counsellor plays an important role in contributing to the development of personal skills in accordance with labour market needs and the socio-economic development of the country, as the counsellor works directly with young individuals. In order for young individuals to choose professions that suit them, it is important to choose career counselling methods that would let the young individuals make the right career choices.

An individual's creative abilities emerge not only from his/her ability to judge logically but, to a large extent, also from his/her intuition and subconscious thinking. Any individual thinks at the verbally logical, figurative (Agejevs, 2005) and abstract levels.

A metaphorical method could be employed by career counsellors for different categories of clients to solve a specific situation or problem. There is a growing interest in the use of metaphor in counselling (Lyddon, Clay, Sparks, 2001).

The choice of a method and the interpretation of the results could encourage the client to make a career decision according to his/her wishes, and the counsellor can offer alternative employment paths, assist in drawing up an individual career development support plan, help to understand the world of employment, promote individual choices and get better integrated into society and professional life. Using a metaphor helps career counsellors to better inform the young individual and understand his/her needs. In the field of professional education, the role of career guidance is growing.

The aim of the study is to analyse the results of applying the metaphorical method in career counselling.

\section{Methodology}

A metaphorical method assignment was given to students, and the results were analysed to achieve the aim of the research. The study was conducted at professional education institutions during career counselling sessions, giving the metaphorical method assignment to young individuals aged 18-30. The study involved 19 students and it was conducted from 1st January 2020 to 30th June 2020.

A questionnaire was developed using a questionnaire template available at the website www.visidati.lv to make it easier and more convenient for the respondents to fill it in. The results were processed using the grouping method, descriptive statistics and MS Excel (Arhipova, Bāliņa, 2003). Using the MS Excel descriptive statistics tool, it is possible to compute the statistical indicators of the participants who participated in the survey.

The research aims to analyse the results of applying the metaphorical method in career counselling.

To achieve the aim of the study, the following specific research tasks were set:

1. to theoretically discuss theories on metaphors;

2. to analyse the results of the metaphorical method assignment.

Theories on metaphors and metaphorical methods were analysed to perform the research tasks and achieve the aim. For a statistical data analysis, descriptive statistics was employed using MS Excel. The metaphorical method assignment was analysed, which is described below. The location of conducting the study: a professional education institution with students who did the assignment online.

\section{Results and discussion}

\section{Development of the concept of metaphorical thinking}

Career metaphors express both the expectations and frustrations felt by the client. Exploring these elements becomes important in the career research process. Metaphors are not only a form of expression but also a way of structuring the mindset. They depict reality in familiar terms, allowing individuals to see events from a specific perspective (Jigau, 2007). A number of scientists have researched the use of 
a metaphorical method in career counselling, e.g., C.A. Storlie, V. Giegerich, T. Stoner-Harris, J. Byrd (2018), D. Tay, J. Huang, H. Zeng (2019), A. Creed, S. Nacey (2020), N.K. Ozdemir (2020), D. Tay (2020), and their findings could be used in the work of career counsellors.

Metaphors are communication instruments that are often used to conceptualize the complex phenomena that surround us (Mignot, 2004). Applying the metaphorical method in career counselling was begun recently and has affected at least two things: one is the conceptualization of the career counselling process and the other is the development of the process itself (Holland, 1997). The second thing involved an overlap of personal and professional features, given that the main goal of career counselling is to find the most suitable career for the individual. This paved the way for the use of metaphors that increased the role of rapid and creative adaptation to changes in social and professional environments. The purpose of career counselling is considered developing a proactive attitude to one's career, which requires flexibility and good opportunity management.

Career counselling is focused on cooperation and an examination of the special role of an individual's career or the so-called "subjective career". A metaphor is not just a "figure of speech." Scholars of the relationship of language to thought advise us that metaphor is more than an affectation, more than a smart way of talking, and more than a means of persuasion: It is a representation of how we think. People's metaphors embody and betray their internal images of the world around them. Using metaphors in our speech, we influence others to share our pictures of the world, and by listening to others' metaphors, we modify our own internal images and develop new ones (Metaphors for careers..., 2020; Inkson, 2002; Inkson, 2004). In addition to other instruments used in career counselling (narratives, exercises for entering into the spirit of imaginary characters, graphical career representations), the metaphorical method helps counsellors and clients to creatively approach career research by using their potential for a complex understanding of career-related phenomena.

In view of the economic, social and cultural transformations that characterize the modern age, the search for meaning and the exploration of personal careers, as well as its connection with other segments of life, are becoming important dimensions of the counselling process (Peavy, 1997; Savickas, 2000, 2001).

Metaphors are common areas of everyday career-related imagery, and metaphors commonly use vivid and familiar characters, thereby giving events a special and personal perspective. The use of metaphors in career counselling can help to reduce the gap between theory and practice and perceive individual aspects of career counselling. The "truth" of the story of career is less important than what it reveals about the client's thinking. K. Inkson categorised nine metaphors of career as inheritance, construction, cycle, matching, journey, encounters and relationships, roles, resource, and story and in later research explored boundaryless and protean careers. Such metaphors may facilitate and highlight alternatively, bias and obscure the understanding of client, practitioners, or both. (Amundson, 1997; Inkson, Amundson, 2002; Inkson, 2006; Creed, 2018).

From a career counselling perspective, metaphors as a way of experiencing reality through aspects common to other situations allow for a deeper career analysis by integrating complex information about these phenomena into a simple image. In career counselling, metaphors create a research context that is beneficial to the individual and allows for the discovery of personal, career-related features (Jigau, 2007). Colour photo cards could be used for metaphors to visualize career situations. Using metaphors, career counselling aims to provide a description of relevant experience, not to give a theoretical interpretation. R.V. Peavy actively supported the idea of transformative energy that emerges when individuals engage in dialogue. Dialogues, including words, symbols, images and metaphors, are useless if they are viewed in isolation from the context in which they emerged. Truth is not born in the head of an individual, as well as not found there; it is born among individuals who seek together a variety of truths through dialogical communication (Peavy, 2004). I. Soika also calls for the use of a diverse dialogue in career counselling, which is a purposeful conversation aimed at a conscious, successive and cognitive activity. It is important to stimulate both the internal dialogue of a young individual and the external dialogue with his/her support persons (Soika, 2015; Soika, 2017).

A metaphor in career counselling is a kind of play that points to:

1) players (counsellors and advice seekers),

2) moves (functions and tactics such as listening or mapping are the moves), 
3) instruments that counsellors use to make moves (e.g., a metaphor is used to change levels of meaning, or computers are used to access information). Moves and instruments are often closely related or even identical, e.g., asking is a move and a question is an instrument. The purpose of career counselling is to bring together on behalf of the advice seeker results such as clearer understanding, feedback, formulation of experience, critical judgments, capacity building initiatives, solutions, self-esteem, plans, need fulfilment, relief from suffering, social support and greater capacity to participate in public life activities (Peavy, 2004).

Metaphors are very often used in socio-dynamic counselling, where counselling is like a learning process, a process of co-construction, a process of life planning and a way to expand one's vision, opportunities, capacities, opportunities and therefore personal freedom. From a socio-dynamic perspective, counselling is primarily a language play. Counselling in a certain way means using a special vocabulary that guides and inspires the counsellor or makes him or her think and act in this way and not otherwise. Maintained relationships and the populated public space are co-constructed by using symbolic and linguistic means. A sentence is said, a metaphor is used, a tone of voice is defined, a word is spoken - all these and countless other linguistic actions are moved in language play in which the meaning is constructed, and symbolic interaction occurs. Human life is associated with language. In everyday life, as well as in counselling, the basic instruments for problem solving are language (intellectual) instruments. Counselling and any solution found during counselling is the result of an interaction that the advice provider and the advice seeker have achieved through interpersonal negotiations. The advice provider and the advice seeker always create a counselling relationship together owing to linguistic and emotional responsiveness and joint conversations (Peavy, 2004).

When a career counsellor tries to understand and describe human actions and unpleasant situations by applying the socio-dynamic approach, irony and caution regarding a literal understanding are preferred. An ironist's way of thinking and expressing him/herself is dialectical, as it tries to contrast the new with the old by using metaphors, figurative sense and humour to expose stagnant ideas and approaches that limit the progress of life.

It is important to use specific examples and metaphors, especially when repeating what has been said, because for many individuals, sayings or metaphors that are common in everyday speech could be expressed much better than technical, abstract or professional terms. It is important to use metaphors to learn different meanings - a metaphor itself is the conveyance of meaning (Peavy, 2004).

\section{Metaphor assignment analysis}

The study was conducted from 1 January 2020 to 30 June 2020. During individual and group career counselling sessions, an assignment was given to 19 professional secondary school students.

As shown in Table 1, the study mainly involved students aged 18 to 30 years, the age range was 12 years, the number of participants was 19 , the mode was 28 , the median was 24 and the arithmetic mean was 24.10 .

Table 1

Age parameters of the young individuals who participated in the study

\begin{tabular}{|c|l|c|}
\hline No. & \multicolumn{1}{|c|}{ Sample parameter } & Value \\
\hline 1 & Mean & 24.10 \\
\hline 2 & Mode & 28 \\
\hline 3 & Median & 24 \\
\hline 4 & Range & 12 \\
\hline 5 & Minimum & 18 \\
\hline 6 & Maximum & 30 \\
\hline 7 & Total number of respondents & 19 \\
\hline
\end{tabular}

The mode is the number appearing most often in a data set (Arhipova, Bālinga, 2003). Most of the students who filled in the questionnaire were aged 28 . The distribution of the respondents by gender was as follows: $78.95 \%$ women, $21.05 \%$ men. 
In the study, the career metaphor "Theatre" was used to depict one's career aspirations (Amundson, 2009). In sociology and in many sources of organizational literature, the career metaphor "theatre" views a person as an "actor" in a play of work and life (Amundson, 2009).

There are at least four types of theatre (Amundson, 2009) that could be defined as follows:

1. Street theatre. A person plays alone or with others, using the street as a stage.

2. Improvisational theatre. A person performs alone or in a small group, using the instructions of the audience. For example, viewers say three words (dirt, pencils, and the royal family) and actors have to perform a play involving those words.

3. Stage. A person works in a larger group, in accordance with the scenario. Each is assigned a specific role, and the play is performed regularly.

4. Film. A group of individuals come together to implement a specific project, and they stay together until the film is completed. It is possible to shoot one frame several times and use special effects.

Doing this exercise, some phrases are said, which are used by individuals to explain why they have chosen a certain type of theatre as the first one.

1. Street theatre: confidence, control, marketing, governance, freedom, independence, creativity, flexibility.

2. Improvisational theatre: cooperation, inspiration, support, adaptation, quick thinking, talents, creativity, imagination, focus on the present, a good sense of humour.

3. Stage: teamwork, coordination, hard work, character building, empathy, magic, energy.

4. Film: teamwork, limited contact with the audience, impression, possibility to re-film, control, heritage, following instructions, material remuneration.

This method is an interesting activity that engages and encourages individuals to reflect on personal and work life values and choices (Amundson, 2009).

A metaphor could include the idea of diverse roles. The person plays several characters at the same time (e.g., an employee, student, parent, friend, association member) and has to play all roles assigned or chosen voluntarily. Counselling can help the person to test and analyse the relationship between the roles played (Jigau, 2007).

The conditions for the assignment given were as follows:

1. Choose one of the pictures that describes your imaginary career (Figures 1, 2, 3, 4).

2. Explain why you chose this picture?

The images for the theatrical metaphor given in the assignment are shown in Figures 1, 2, 3, 4.

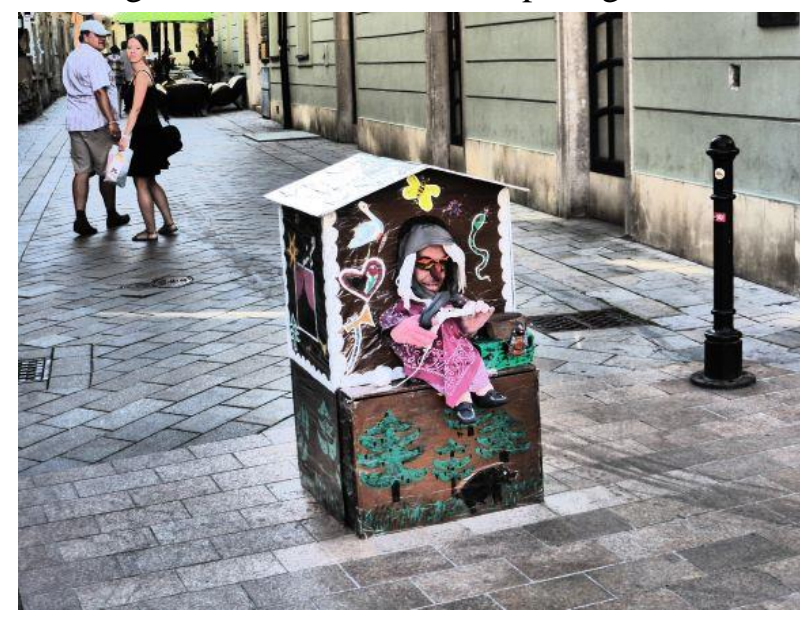

Figure 1. Road Street Scene. Puppet Theatre (Road Street..., 2020).

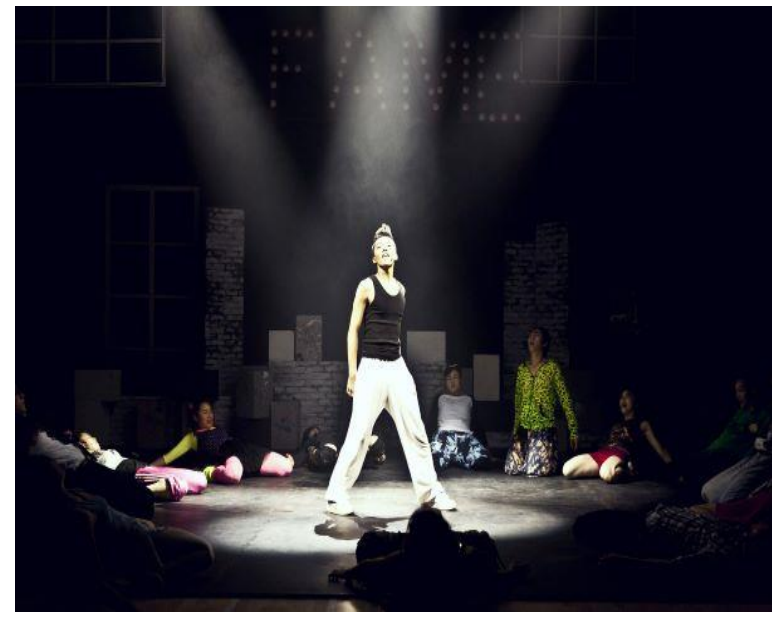

Figure 2. Dance, People, Theatre, Monologue

(Dance..., 2020). 


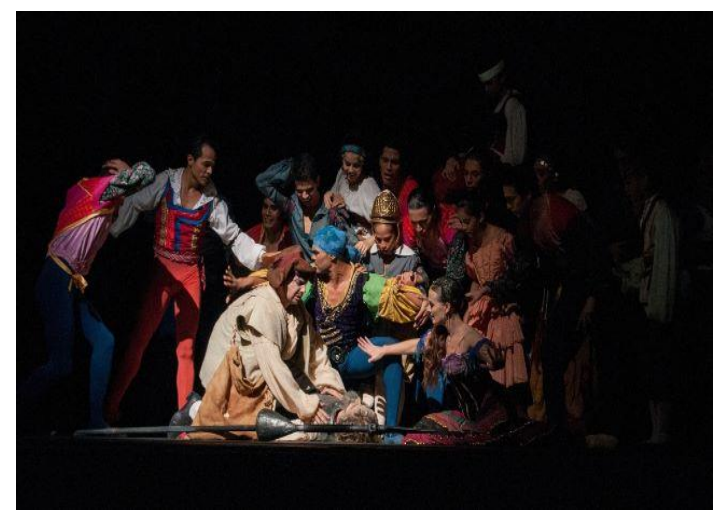

Figure 3. Ballet Don Quijote. Theatre, Performance, Stage, Actors (Ballet Don..., 2020).

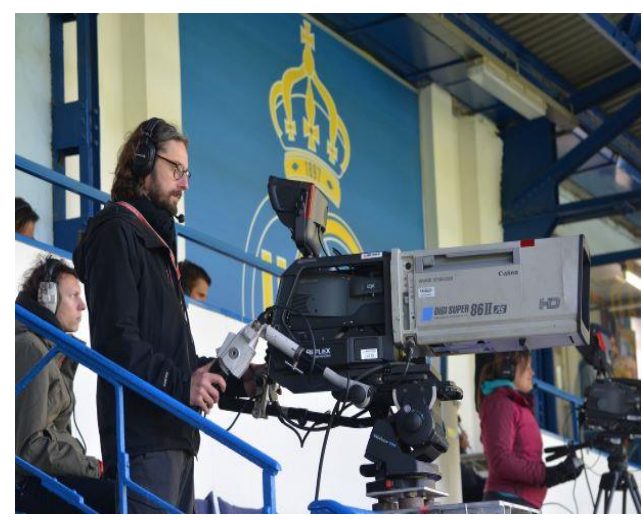

Figure 4. Camera, Cameraman, Job, People, Filming, Man (Camera..., 2020).

According to the results of the study, $36.8 \%$ respondents had chosen Figure 2 and Figure 3, $15.8 \%$ had chosen Figure 3 and $10.5 \%$ had chosen Figure 2 to describe their potential careers (Table 2).

Table 2

Percentage breakdown of the figures selected by the respondents

\begin{tabular}{|l|l|c|c|}
\hline No. & Figure No. & Number of respondents & \% \\
\hline 1 & Figure 1 & 2 & $10.5 \%$ \\
\hline 2 & Figure 2 & 7 & $36.8 \%$ \\
\hline 3 & Figure 3 & 7 & $36.8 \%$ \\
\hline 4 & Figure 4 & 3 & $15.8 \%$ \\
\hline Total & & 19 & $100.0 \%$ \\
\hline
\end{tabular}

Respondents' answers to the question "Why did you choose this picture?":

Figure 1:

- the work is interesting, but not active;

- I do not know why.

Figure 2:

- because it had only one character;

- I want to be respected in my workplace;

- because I only want to progress in my life;

- the central character in the image seems strong, bright and confident;

- I want to be the centre of attention;

- because I like being on stage;

- I do not know why.

Figure 3:

- I liked it more than the others because it reminds me of support to me;

- because I have always had a job where teamwork plays an important role, yet at the same time the work done is individual (for five years I have worked as a journalist in two companies);

- because there are a lot of individuals in the team, and everyone is fighting for their place;

- because it is teamwork;

- successful career development will require cooperation, support and communication with a variety of individuals.

Figure 4:

- I never liked the dance, art and theatre industry; therefore, I prefer technology-related things;

- I am not in a hurry and, at first, I look at it as if doing it from the side;

- it has to be important to me, but I am not a hard-working person and not a clown. 
The author concludes that the use of metaphor assignments in career counselling helps young individuals to:

- creatively think about a career;

- get to know and understand themselves, i.e., what is important, what is less important;

- easily adapt to the demands of everyday life at work and in the group;

- identify the causes of professional dissatisfaction;

- learn the environment and imagine the way they would like to work.

Career counsellors have an opportunity to use metaphor assignments as a career method online. This method allows counsellors to work with clients who are introverts, as well as it helps to identify the client's wishes and the first requirements for career choice at the "ice-breaking" stage. Online tools in career counselling are easy to use as interactive cooperation assessment tools to help clients make career decisions. They could be particularly useful in tailoring the counselling process to clients' needs and helping the clients to acquire the key decision-making and digital competencies needed in our knowledge society (Racene, Dislere, 2014). During career counselling sessions, young individuals give answers and are spontaneously involved in the use of metaphors in their exercises. The counsellor's duty is to present the diagnostic results in an understandable way and to explain that the results of the assignments done only show a trend, and therefore it is necessary to interpret the results in a neutral way (Racene, 2017).

The traditional forms of counselling are characterized by adherence to a long-established vocabulary, which is aging and, to some extent, losing its usefulness. Society is changing rapidly, and as the society changes, individuals are changing and so does the vocabulary and methods they use to describe life experiences. For counselling to remain relevant and meet the needs of those seeking advice in today's society, it should also change, both in terms of words and methods used. Therefore, the method of using metaphors online is very relevant today, as new ideas are needed in career counselling to start a new communication play that will be accepted by the next generation of counsellors and clients. The unpredictability and changing nature of today's society means that new types of counselling are needed, and the career metaphor "Theatre" for portraying one's career aspirations is a great way for career counsellors to work with clients online.

\section{Conclusions}

- The metaphorical method gives an idea of young individuals' creativity and imagination in relation to career development.

- The metaphorical method helps counsellors and clients creatively approach career research, using their potential for a complex understanding of career-related phenomena.

- For some clients, sayings or metaphors that are common in everyday speech could be expressed much better than technical, abstract or professional terms.

- The career metaphor "Theatre" is an interesting activity that engages and encourages individuals to reflect on personal and work life values and choices.

- The career counsellor can create new, unique assignments adapted to his/her target audience.

- The metaphorical method is suitable for applying it both in person and online.

\section{Bibliography}

1. Agejevs V. (2005). Semiotika [Semiotics]. Rīga: Jumava. (in Latvian)

2. Amundson E.N. (2009). Active Engagement: The Being and Doing of Career Counselling ( $3^{\text {rd }}$ ed). Vancouver: Ergon Communications.

3. Amundson N. (1997). Myths, Metaphors and Moxie: The 3M's of Career Counseling. Journal of Employment Counseling, 34(2), 78-84. doi: 10.1002/j.2161-1920.1997.tb00461.x

4. Arhipova I., Bāliņa S. (2003). Statistika ekonomikā. Risinājumi ar SPSS un Microsoft Excel [Statistics in Economics. Solutions with SPSS and Microsoft Excel]. Riga: Datorzinību centrs. (in Latvian).

5. Ballet Don Quijote. Theatre, Performance, Stage, Actors. (2020). [Image]. Retrieved from https://pixabay.com/photos/ballet-don-quijote-theatre-895062/

6. Briska L., Dislere V. (2018). Guidance Model for Promoting Self-Directed Career Decision-Making by Secondary School Students. In V. Dislere (Ed.), The Proceedings of the International Scientific 
Conference Rural Environment. Education. Personality (REEP), 11. Jelgava: Latvia University of Life Sciences and Technologies, 344-350. doi: 10.22616/REEP.2018.042

7. Camera, Cameraman, Job, People, Filming, Man. (2020). [Image]. Retrieved from https://pixabay.com/photos/camera-cameraman-job-people-filming-1355487

8. Creed A. (2018). Career Guidance: Metaphors Matter. Retrieved from https://accellresearch.com/2018/02/05/in-career-guidance-metaphors-matter/

9. Creed A., Nacey S. (2020). Metaphor Analysis in Vocational Counselling: Moving from Intuitive to Reliable Metaphor Identification. British Journal of Guidance and Counselling. doi: 10.1080/03069885.2020.1763915

10. Dance, People, Theatre, Monologue. (2020). [Image]. Retrieved from https://pixabay.com/photos/dance-people-theatre-monologue-430553

11. Dislere V., Vronska N. (2020). Evaluation of Career Counsellors' Competences in Career Guidance. In V. Dislere (Ed.), The Proceedings of the International Scientific Conference Rural Environment. Education. Personality (REEP), 13. Jelgava: Latvia University of Life Sciences and Technologies, 385-399. doi: 10.22616/REEP.2020.046

12. Holland J. L. (1997). Making Vocational Choices: A Theory of Vocational Personalities and Work Environments. ( $3^{\text {rd }}$ ed.). Englewood Cliffs, NJ: Prentice Hall.

13. Inkson K. (2002). Thinking Creatively about Careers: The Use of Metaphor. In M.A. Peiperl, M.B. Arthur, N. Anand, Career Creativity: Explorations in the Re-making of Work. Oxford, UK: Oxford University Press, 15-34.

14. Inkson K. (2004). Images of Career: Nine Key Metaphors. Journal of Vocational Behavior 65(1), 96-111. doi: 10.1016/S0001-8791(03)00053-8

15. Inkson K. (2006). Metaphor: A New Way of Thinking About Careers. Retrieved from https://www.ncda.org/aws/NCDA/page_template/show_detail/5132?model_name=news_article

16. Inkson K., Amundson N. (2002). Career Metaphors and Their Application in Theory and Counselling Practice. Journal of Employment Counselling, 39(3), 98-108. doi: 10.1002/j.21611920.2002.tb00841.x

17. Jigau M. (Ed.). (2007). Career Counselling - Compendium of Methods and Techniques. Bucharest: AFIR.

18. Lyddon W.J., Clay A.L., Sparks C.L. (2001). Metaphor and Change in Counselling. Journal of Counselling and Development, 79(3), 269-274. doi: 10.1002/j.1556-6676.2001.tb01971.x

19. Metaphors for careers. (2020). Career Research. Retrieved from http://career.iresearchnet.com/career-development/metaphors-for-careers/

20. Mignot P. (2004). Metaphor and "career". Journal of Vocational Behavior, 64(3), 455-469. doi: 10.1016/j.jvb.2003.12.014

21. Ozdemir N.K. (2020). A Creative Method for Career Supervision: Therapeutic Associative Cards. Australian Journal of Career Development, 29(2), 144-150. doi: 10.1177/1038416220927795

22. Peavy R.V. (1997). A Constructive Framework for Career Counseling. In T.L. Sexton, B.L. Griffen (Eds.), Constructivist Thinking in Counseling Practice, Research, And Training. New York: Teachers College Press, 122-141.

23. Peavy R.V. (2004). SocioDynamic Counselling: A Practical Approach to Meaning Making. Taos Institute Publications.

24. Racene A. (2013). Factors Determining Successful Women Careers. In V. Dislere (Ed.), The Proceedings of the International Scientific Conference Rural Environment. Education. Personality (REEP), 6. Jelgava: LLU, 138-145. Retrieved from https://llufb.llu.lv/conference/REEP/2013/LatviaUniv-Agricult_REEP_2013_ISSN_2255-808X-138-145.pdf

25. Racene A. (2017). Importance of Goal-Setting Tasks in Career Counselling. In V. Dislere (Ed.), The Proceedings of the International Scientific Conference Rural Environment. Education. Personality (REEP), 10. Jelgava: LLU, 442-450. Retrieved from https://lufb.llu.lv/conference/REEP/2017/Latvia-Univ-Agricult-REEP-2017_proceedings-442-450.pdf

26. Racene A., Dislere V. (2014). Internet tools as a kind of career e-guidance. In V. Dislere (Ed.), The Proceedings of the International Scientific Conference Rural Environment. Education. Personality (REEP), 7. Jelgava: LLU, 200-207. Retrieved from https://llufb.llu.lv/conference/REEP/2014/Latvia-Univ-Agricult-REEP-2014proceedings-200-207.pdf 
27. Road Street Scene. Puppet Theatre. (2020). [Image]. Retrieved from https://pixabay.com/photos/road-street-scene-puppet-theatre-356809/

28. Savickas M.L. (2000). Renovating the Psychology of Careers for The Twenty-First Century. In A. Collin, R.A. Young (Eds.), The Future of Career. Cambridge, United Kingdom: Cambridge University Press, 53-68. doi: 10.1017/CBO9780511520853.004

29. Savickas M.L. (2001). The Next Decade in Vocational Psychology. Mission and Objectives. Journal of Vocational Behavior, 59(2), 284-290. doi: 10.1006/jvbe.2001.1834

30. Soika I. (2015). Entity of Dialogue in Career Guidance of Secondary Vocational Schools. In V. Dislere (Ed.), The Proceedings of the International Scientific Conference Rural Environment. Education. Personality, 8. Jelgava: LLU, 338-346. Retrieved from https://lufb.llu.lv/conference/REEP/2015/Latvia-Univ-Agricult-REEP-2015proceedings-338-346.pdf

31. Soika I. (2017). Evolution of Dialogue for Students' Career Guidance in Secondary Vocational Education. In V. Dislere (Ed.), The Proceedings of the International Scientific Conference Rural Environment. Education. Personality (REEP), 10. Jelgava: LLU, 481-488. Retrieved from https://llufb.llu.lv/conference/REEP/2017/Latvia-Univ-Agricult-REEP-2017_proceedings-481-488.pdf

32. Storlie C.A., Giegerich V., Stoner-Harris T., Byrd J. (2018). Conceptual Metaphors in Internship: Creative Journeys in Counselor Development. Journal of Creativity in Mental Health, 13(3), 331-343. doi: 10.1080/15401383.2018.1439790

33. Tay D. (2020). Affective Engagement in Metaphorical Versus Literal Communication Styles in Counselling. Discourse Processes, 57(4), 360-375. doi: 10.1080/0163853X.2019.1689086

34. Tay D., Huang J., Zeng H. (2019). Affective and Discursive Outcomes of Symbolic Interpretations in Picture-Based Counselling: A Skin Conductance and Discourse Analytic Study. Metaphor and Symbol, 34(2), 96-110. doi: 10.1080/10926488.2019.1611724

35. Vygotsky L.S., Luria A. (1994). Tool and Symbol in Child Development. In R. Van Der Veer, J. Valsiner (Eds.), The Vygotsky Reader. London: Basil Blackwell, 99-174. 